\title{
Influence of Household Environment and Maternal Behaviors to Upper Respiratory Infection among Toddlers
}

\section{Pengaruh Lingkungan Rumah Tangga dan Perilaku Ibu terhadap Kejadian Infeksi Saluran Pernapasan Akut Atas pada Anak Bawah Lima Tahun}

\author{
Reny Fahdiyani*, Ardini Saptaningsih Raksanagara**, Hadyana Sukandar***
}

*Master of Public Health, Faculty of Medicine, Padjajaran University, Bandung, Indonesia**Department of Public Health, Faculty of Medicine, Padjajaran University, Bandung, Indonesia, ***Department of Biostatistics, Faculty of Medicine, Padjajaran University, Bandung, Indonesia

DOI: http://dx.doi.org/10.21109/kesmas.v10i3.589

\begin{abstract}
Upper respiratory infection (URI) in developing countries causes high morbidity among toddlers. Indonesia Health Ministry reported that non-pneumonia acute respiratory infection (ARI) increased by $2.6 \%$ from 2007 to 2011. Risk factors which may contribute to URI include environment and behavior. This study aimed to investigate environmental and behavioral factors with URI among toddlers. This case control study was conducted on February - April 2015 among toddlers in Tamansari that is a slum area in Bandung City. Case was 55 mothers with toddlers suffering from URI who came to primary health care, meanwhile control was twice bigger than cases selected from the environment and matched for age, sex and nutritional status. Environmental factors were density, humidity, ventilation, temperature and smoke disposal. Meanwhile, behavioral factors were hand-washing, mother's smoking behavior, the use of mask, vitamin A consumption and exclusive breastfeeding. Results of study showed that environmental factor related to URI was only density with $p$ value $=0.021$ and $O R=2.843$ $(\mathrm{Cl} 95 \%=1.168-6.920)$. None of maternal behavior factor was related to URI. Reducing density is an important and challenging issue in slum area, same as similary health promotion and prevention concerning URI are still necessary to reduce the risk of this disease among toddlers in urban slum area.

Keywords: Behavioral factors, environmental factors, toddlers, upper respiratory infection

\footnotetext{
Abstrak

Infeksi saluran pernapasan akut atas (ISPA atas) di negara berkembang menyebabkan morbiditas tinggi pada anak bawah usia lima tahun (balita). Kementerian Kesehatan Republik Indonesia melaporkan bahwa ISPA nonpneumonia meningkat 2,6\% dari tahun 2007 ke 2011. Faktor risiko yang dapat berkontribusi termasuk lingkungan dan perilaku. Penelitian ini bertujuan
}

untuk menyelidiki faktor perilaku dan lingkungan dengan ISPA atas pada balita. Studi kasus kontrol ini dilakukan dari Februari-April 2015 pada balita di Tamansari yang merupakan daerah kumuh di Kota Bandung. Kasus adalah 55 ibu dengan balita menderita ISPA atas yang datang ke puskesmas, sedangkan kontrol dua kali lebih besar dari kasus dipilih dari lingkungan dan cocok untuk usia, jenis kelamin, dan status gizi. Faktor lingkungan adalah kepadatan, kelembaban, ventilasi, suhu, dan pembuangan asap. Sedangkan perilaku adalah mencuci tangan, perilaku merokok ibu, pemakaian masker, konsumsi vitamin A dan ASI eksklusif. Hasil penelitian menunjukkan bahwa faktor lingkungan yang berkaitan dengan ISPA atas hanya kepadatan dengan nilai $p=0,021$ dan $\mathrm{OR}=2,843(\mathrm{Cl} 95 \%$ : $1,168-6,920)$. Tidak terdapat faktor perilaku ibu yang berhubungan dengan ISPA atas. Pengurangan kepadatan merupakan masalah penting dan menantang di daerah kumuh, sama halnya dengan promosi kesehatan dan pencegahan tentang ISPA atas masih penting untuk mengurangi risiko penyakit ini pada balita di daerah kumuh perkotaan.

Kata kunci: Faktor perilaku, faktor lingkungan, balita, infeksi saluran pernapasan akut atas

Introduction

Acute respiratory infection (ARI) is a common global health problem that causes approximately 4.25 million deaths in the world each year and places the fourth rank as the cause of death at any age after cancer. ${ }^{1}$ Moreover, children are suffering from this disease about $6-12$ times per year. This repetitive frequency causes the

Correspondence: Reny Fahdiyani, Master of Public Health, Faculty of Medicine, Padjadjaran University, Bandung, Sadang Hegar I Street No. 4, Bandung, West Java, 40134,Phone: 022-7795594,e-mail:fahdiyani86@yahoo.com 
high number of visits to primary care physicians. In the United States, approximately 25 million patients visited to primary health care and 1.6 million patients came to the emergency section in hospitals every year because of influenza caused mainly by virus. ${ }^{2,3}$

Although ARI can recover by its own without any particular intervention and rarely require antibiotics, not all parents understand that the infection is often overlooked and spread to the lower respiratory tract and middle ear that lead to complications and requiring more complex interventions. ${ }^{4}$ Approximately $20 \%$ of children with respiratory infections have complications and more than $24 \%$ require ongoing consultations. Upper respiratory infection (URI) causes the loss of working days and absenteeism in schools and leading to high morbidity among children. Prevention from this disease is important, but behaviors to prevent the spread of infectious diseases through the transmission medium remains less positive. ${ }^{5-6}$

Indonesia is one of developing countries with $40 \%$ of global ARI death rate. This disease is also placed at the first rank due to the cause of Disability-Adjusted Life Year (DALY). ${ }^{7,8}$ Indonesia Health Ministry has reported that non-pneumonia ARI has increased by $2.6 \%$ from 2007 to $2011 .{ }^{9}$ Data from the Basic Health Research in 2013 found that the period prevalence of ARI based on diagnosis of health workers and complaints of residents was $25 \%$. Toddlers were the group aged 1 - 4 years highest among all ages. 1,10

The period prevalence of ARI in West Java was $24.8 \%$ and according to data from the Regional Socioeconomic Survey in 2012, worth to $47.77 \%$ of people suffering from respiratory diseases (cough, runny nose, shortness of breath). ${ }^{10-11}$ Data from Bandung Health Agency showed an increase of ARI at the age of 1 - 4 years by $86 \%$ from 2012 to $2013.12-13$ This suggested that respiratory disease was common among communities in West Java and the incidence was higher among toddlers as its prevalence increased in slum areas with a high density.

Tamansari is a slum area with the highest number of people around the Cikapundung River with 28,729 residents. This area is on the edge of Cikapundung River with the dirty environmental condition. The toddlers living here are more susceptible suffering from respiratory infection. It was reported that there were 817 toddlers suffering from URI in slum areas in Tamansari in 2012.12 Various factors contribute as risk factors of URI, such as age, sex, birth characteristics, ethnicity, breastfeeding, socioeconomic factors, condition of houses, population density, passive smokers, daycare, and household behaviors. ${ }^{14-17}$

There are two types of ARI namely upper respiratory infection (URI) and lower respiratory infection (LRI).
The most common case that occurs among toddlers is URI in which URI is an infection occuring in human upper respiratory tract including nostrils, nasal cavity, pharynx and larynx. ${ }^{18}$ URI common symptoms are cough, cold with or without shortness of breath. Other symptoms are hard to breath, sore throats, fever, and earache. ${ }^{19-20}$ This study aimed to investigate environmental and behavioral factors related to URI among toddlers in Tamansari, Bandung.

\section{Method}

A case control study was conducted on February to April 2015 in areas located in Tamansari to investigate the relation of household environment and maternal behavior factors significantly contribute to URI among toddlers. Inclusion criteria for the cases were mothers with toddlers suffering from URI aged $0-59$ months who came to primary health care and diagnosed according to International Code of Diseases (ICD) 10 (J00- J06), having a good nutritional status based on height/weight and willing to participate in the study after signing informed consent of the study. The exclusion criteria for cases were mothers with toddlers aged $0-59$ months suffering from other concomitant diseases (tuberculosis, asthma, congenital heart disease), having a record of allergy in the family and was not in place at the time of the study. As case there were such 55 patients who met the inclusion criteria and were selected by consecutive sampling.

Two controls were selected from environment of each case. They were mothers with healthy toddlers aged $0-$ 59 months in Tamansari environment, not diagnosed suffering from URI and other concomitant diseases such as tuberculosis, asthma or heart diseases, matched for age (more or less three months of the case), sex, and nutritional status same as the case and willing to participate in the study after signing the informed consent of the study. The exclusion criterion was mothers who were not in the place at the time of the study. There were 110 controls chosen by random sampling and the information was collected by visiting children's houses.

Subvariables of household environment were recorded by following the Indonesia Healthy House Evaluation Guidance 2002 for ventilation meter and kitchen smoke disposal. ${ }^{21}$ In addition, subvariables were recorded by obeying the Regulation of Health Ministry No. 1077/Menkes/per/V/2011 for temperature and humidity. ${ }^{22}$ Subvariables of maternal behavior were measured by questionnaires validated with face validity from two experts and the reliability of the questionnaire was 0.702 of cronbach alpha. Mother's literacy towards knowledge of URI's prevention quetionnaire had reliability 0.742 of cronbach alpha. Mothers' knowledge of URI was measured by 10 items of Health Literacy Skills Instrument (HLSI). $23-24$ 
Dependent variable was the incidence of URI among toddlers aged $0-59$ months who were already diagnosed by a doctor/health worker at primary health care with the symptoms of cough with phlegm/mucus/dry, cold, fever or without fever, without the twitching of the muscle wall of the lower chest to the lungs which lasts up to 14 days in accordance with the ICD 10 (J.00 - J.06).

Independent variable was household environment namely ventilation (comparison between the width of air circulation holes from inside to outside and vice versa and the width of entire floors in the house). According to Indonesia Healthy House Evaluation Guidance 2002, healthy house meets the requirements of having more than $10 \%$ from the width of entire floors in the house of air ventilation. In case if less than $10 \%$, it does not fulfill the criteria of healthy house. In term of room temperature, according to Regulation of Health Ministry in 2011 for quantitative measurement towards temperature in a room, it meets the requirement if the temperature is between $18^{0} \mathrm{C}-30^{0} \mathrm{C}$. Then in term of humidity, the vapour size in the room stated by percentage (\%) meets the standard if between $40-60 \% \mathrm{Rh}$ based on Regulation of Health Ministry. In term of kitchen smoke disposal, there is kitchen disposal for smoke circulation that meets the criteria if the width is more than $10 \%$ from the width of kitchen floor, while it does not meet the criteria if the width is less than $10 \%$ from the width of kitchen floor. Furthermore, in term of density comparing the total width of the house and the permanent residents, it is dense if the comparison less than eight meter square). ${ }^{21}$

Maternal behavior factors were hand-washing (behavior of toddlers' mothers who always wash their hands with soap and flowly water before eating, feeding, breastfeeding, after coughing and sneezing, and washing children's hands with soap before and after meals and after playing outside); the use of mask (wearing facial mask as protection from URI which covers nose and mouth by mothers when suffering from URI); mothers' smoking behavior (mother's smoking habits around the house); exclusive breatfeeding (only breastfeeding during the first six months of the babies or according to baby's age under six months during interview); vitamin A consumption (distributing vitamin A from integrated health care on February and August).

Confounding factors were immunization records (immunization given to babies based on to immunization months), mothers' educational background (the latest formal education of mothers), mothers' literacy towards URI (knowledge of URI using 10 items of HLSI and knowledge of URI prevention), low birthweight (newborn baby's weight less than 2,500 gram according to WHO). Chi-square test and binary logistic regression analysis were applied in environmental factors like density, humidity, ventilation, temperature, smoke disposal. Behavioral factors were hand-washing, mothers' smoking behavior, the use of mask, vitamin A consumption and exclusive breastfeeding.

\section{Results}

Table 1 above showed that household environmental factors such as ventilation, temperature, kitchen smoke disposal had no significant relation to URI. However, humidity $(\mathrm{p}$ value $=0.043)$ and density $(\mathrm{p}$ value $=0.030)$ had significant relation to URI and eligible for included in multivariable analysis ( $p$ value $<0.25$ ).

Maternal behavior factors, such as hand-washing, the use of mask, vitamin A consumption and exclusive breastfeeding were not significantly related to URI. However, mothers' smoking behavior $(p$ value $=0.097$ ) was eligible for multivariable analysis using binary logistic regression ( $\mathrm{p}$ value $<0.25$ ) (Table 2 ).

In the multivariable analysis using binary logistic regression (Table 4), humidity and density appeared as subvariables in the final model. However, density was the most influential factor to respiratory infection related to URI with $\mathrm{p}$ value $=0.021(\mathrm{OR}=2.843$; CI $95 \%=1.168$ $-6.920)$.

Table 1. Household Environment and Upper Respiratory Infection

\begin{tabular}{lllllll}
\hline Variable & Subvariable & $\begin{array}{l}\text { Cases } \\
(\mathbf{n}=\mathbf{5 5})\end{array}$ & $\begin{array}{l}\text { Control } \\
(\mathbf{n = 1 1 0})\end{array}$ & p value & OR Crude & 95\%CI \\
\hline House ventilation & Not meet the criteria & $21(38.2)$ & $36(32.7)$ & 0.487 & 1.270 & $(0.647-2.492)$ \\
& Meet the criteria & $34(61.8)$ & $74(67.3)$ & & & \\
Temperature & Not meet the criteria & $3(5.5)$ & $2(1.8)$ & 0.334 & 3.115 & $(0.505-19.219)$ \\
& Meet the criteria & $52(94.5)$ & $108(98.2)$ & & & \\
Humidity & Not meet the criteria & $48(87.3)$ & $106(96.4)$ & $0.043^{* * * *}$ & 0.259 & $(0.072-0.926)$ \\
& Meet the criteria & $7(12.7)$ & $6(3.6)$ & & & \\
Kitchen Smoke Disposal & Yes, but inadequate & $33(60)$ & $43(39.1)$ & 0.387 & & \\
& Yes, adequate & $19(34.5)$ & $62(56.4)$ & 0.748 & & \\
\multirow{5}{*}{ Density } & No kitchen & $3(5.5)$ & $5(4.5)$ & 0.484 & & \\
& Not meet the criteria & $47(85.5)$ & $77(70)$ & $0.030^{* * *}$ & 2.518 & $(1.073-5.911)$ \\
& Meet the criteria & $8(14.5)$ & $33(30)$ & & & \\
\hline
\end{tabular}

**:Included into multivariable analysis 
Table 2. Maternal Behaviors and Upper Respiratory Infection

\begin{tabular}{|c|c|c|c|c|c|c|}
\hline Variable & Subvariables & $\begin{array}{l}\text { Cases } \\
(n=55)\end{array}$ & $\begin{array}{l}\text { Control } \\
(\mathrm{n}=110)\end{array}$ & p value & OR Crude & 95\%CI \\
\hline Hand-washing & $<$ Median & $22(40)$ & $46(41,8)$ & 0,823 & 1,078 & $(0,558-2,084)$ \\
\hline & $\geq$ Median & $33(60)$ & $64(58,2)$ & & & \\
\hline The use of mask & $\begin{array}{l}<\text { Median } \\
\geq \text { Median } 3\end{array}$ & $\begin{array}{l}24(43,6) \\
1(56,4)\end{array}$ & $\begin{array}{l}47(42,7) \\
63(57,3)\end{array}$ & 0,911 & 0,964 & $(0,501-1,852)$ \\
\hline Mothers' smoking behavior & $\begin{array}{l}\text { Yes, smoking } \\
\text { Not smoking }\end{array}$ & $\begin{array}{l}5(9,1) \\
50(90,9)\end{array}$ & $\begin{array}{l}21(19,1) \\
89(80,9)\end{array}$ & $0,097^{* * *}$ & 0,424 & $(0,151-1,193)$ \\
\hline Vitamin A consumption & $\begin{array}{l}\text { No } \\
\text { Yes }\end{array}$ & $\begin{array}{l}4(7,3) \\
51(92,7)\end{array}$ & $\begin{array}{l}5(4,5) \\
105(95,5)\end{array}$ & 0,483 & 1,647 & $(0,424-6,396)$ \\
\hline Exclusive breastfeeding & $\begin{array}{l}\text { No } \\
\text { Yes }\end{array}$ & $\begin{array}{l}18(32,7) \\
37(67,3)\end{array}$ & $\begin{array}{l}43(39,1) \\
67(60,9)\end{array}$ & 0,425 & 0,758 & $(0,384-1,498)$ \\
\hline
\end{tabular}

***Included into multivariable analysis

Table 3. Confounding Factors Related to Upper Respiratory Infection

\begin{tabular}{|c|c|c|c|c|c|c|}
\hline Characteristics & Category & $\begin{array}{l}\text { Cases } \\
(n=55)\end{array}$ & $\begin{array}{l}\text { Control } \\
(\mathrm{n}=110)\end{array}$ & p value & OR Crude & $95 \% \mathbf{C I}$ \\
\hline \multirow[t]{3}{*}{ Educational background } & $\leq$ Graduated from elementary school & $5(9.1)$ & $9(8.2)$ & 0.757 & & \\
\hline & Graduated from junior high school & $13(23.6)$ & $21(19.1)$ & 0.472 & & \\
\hline & $\geq$ Graduated from senior high school & $37(67.3)$ & $80(72.7)$ & & & \\
\hline \multirow[t]{2}{*}{ URI prevention knowledge } & Poor knowledge & $29(52.7)$ & $70(63.6)$ & $0.178^{* * *}$ & 0.637 & $(0.331-1.229)$ \\
\hline & Good knowledge & $26(47.3)$ & $40(36.4)$ & & & \\
\hline \multirow[t]{2}{*}{ HLSI } & Inadequate & $22(40)$ & $37(33.6)$ & 0.421 & 1.315 & $(0.674-2.568)$ \\
\hline & Adequate & $33(60)$ & $73(66.4)$ & & & \\
\hline \multirow[t]{2}{*}{ Baby's birthweight } & Low birthweight & $5(9.1)$ & $16(14.5)$ & 0.322 & 0.588 & $(0.203-1.698)$ \\
\hline & Normal birthweight & $50(90.9)$ & $94(85.5)$ & & & \\
\hline \multirow[t]{2}{*}{ Baby's immunization records } & Incomplete & $6(10.9)$ & $7(6.4)$ & 0.362 & 1.802 & $(0.575-5.646)$ \\
\hline & Complete & $49(89.1)$ & $103(93.6)$ & & & \\
\hline
\end{tabular}

Table 4. Factors Related to Upper Respiratory Infection Simultanuously with Binary Logistic Regession

\begin{tabular}{lllllll}
\hline Variable & Subvariables & Coef. B & SE (B) & p value & OR Adj & 95\%CI \\
\hline \multirow{2}{*}{ First model } & Humidity (not meet the criteria) & -1.479 & 0.689 & 0.032 & 0.228 & $(0.059-0.879)$ \\
& Density (not meet the criteria) & 1.008 & 0.467 & 0.031 & 2.740 & $(1.098-6.840)$ \\
& Mothers' smoking behavior (yes, smoking) & -0.695 & 0.550 & 0.207 & 0.499 & $(0.170-1.469)$ \\
& URI's prevention knowledge (Poor) & -0.636 & 0.369 & 0.085 & 0.529 & $(0.257-1,091)$ \\
Final model & Humidity (not meet the criteria) & -1.552 & 0.680 & 0.023 & 0.212 & $(0.056-0.803)$ \\
& Density (not meet the criteria) & 1.045 & 0.454 & 0.021 & 2.843 & $(1.168-6.920)$ \\
\hline
\end{tabular}

\section{Discussion}

Results of this study showed household environmental factors, such as ventilation of the house was not significantly associated with URI ( $\mathrm{p}$ value $=0.480$; $\mathrm{OR}=$ $1.27(95 \% \mathrm{CI}=0.64$ to 2.49$))$. This means that any comparison with the ventilation around the floor of the house gave the same effect on the incidence of URI among toddlers. The narrow land in Tamansari was one of the factors, so the ventilation became not very significant to URI. House ventilation is one of factors that causes respiratory infection on toddlers among others. No significant association between ventilation and URI could be due to other factors that contribute to this disease, such as the density of the house. House structure in Tamansari is very closed between them. The number of household member in the house was also concomitant factor influencing to URI. The house ventilation qualified with the criteria yet had a higher number of household members would have the same risk with the unqualified house ventilation yet had fewer number of members. A source of transmission of agents and body endurance also affected URI among toddlers. Children with decreasing endurance who lived in the house with qualified ventilation and ill family member could be infected with URI.

This study was different from case-control study on 0 - 5 year-old children who suffered from ARI and looked for treatment at primary health care on March -April 2009 at Karangnongko Klaten Primary Health Care. Results of chi-square test was with $p$ value $=0.000$ ( $p<$ $0.05)$. This means that there was a significant correlation between ventilation with respiratory infection, in other words, the house with unqualified ventilation was proven to be a risk factor for respiratory disease with the OR = 5.125. It showed that children living in houses with an 
area of ventilation that was not eligible had the risk of respiratory diseases 5.125 times higher than with children who lived in houses with qualified ventilation. ${ }^{25}$

Temperature was not significantly associated with URI $(\mathrm{p}$ value $=0.330 ; \mathrm{OR}=3.11(\mathrm{CI} 95 \%=0.50$ to 19.21)). This means that the temperature of the room in the house had the same effect on the incidence of URI among toddlers. The average of daily temperature in Bandung in the mornings, afternoons and evenings did not experience significant changes. These results together with the results of cross-sectional study in Penjaringan Subdistrict, Rungkut District, Surabaya City in 155 houses. Results of this study suggested that there was no relation between the temperature of the room with the incidence of ARI among toddlers ( $p$ value $=$ 0.179). ${ }^{26}$ It was different with the result in Finland which suggested that there was a relation between the temperature of the common cold $(\mathrm{p}$ value $=0.017)$ and pharyngitis $(\mathrm{p}$ value $=0.011)$. Every reduction of $1^{0} \mathrm{C}$ would increase the risk of respiratory infection $4.3 \%$ (p value $=0.0001)$ and the common cold $2.1 \%(\mathrm{p}$ value $=$ $0.004) .27$

Humidity analysis on bivariable using chi-square analysis had $\mathrm{p}$ value $=0.043$ with $\mathrm{OR}=0.259(\mathrm{CI} 95 \%$ $=0.072$ to 0.926$)$ ), using multiple logistic regression, the humidity had $\mathrm{p}$ value $=0.023$ with $\mathrm{OR}=0.212(\mathrm{CI} 95 \%$ $=0.056$ to 0.803$)$. Humidity had $p$ value $<0.05$, but this was not supported by CI value in which lower values below one meaning that there was no significant relation between URI and humidity among toddlers. This showed that the moisture was a protective factor for the incidence of URI. House with unqualified humidity did not cause URI. It was because the children spent most of their times in the house and partly outside the house.

Frequency and duration of children playing outside were other factors that influence the transmission of URI because children could be contagious from their neighbour friends or others outside the house. Air humidity in the house was influenced by weather condition and temperature levels outside the house, how the building is protected from moisture and others as well as leakage, activities such as bathing, steaming, drying wet clothes, etc. Bandung is located at an altitude of 791 meter above sea level, the highest point in the northern region with an altitude of 1,050 meters and the lowest is south side by 675 meter above sea level. Bandung climate is influenced by the humidity of the mountain climate. Average temperature of $23.1^{0} \mathrm{C}$, average rainfall of 204.11 millimeters, and the number of rainy days on average 18 days per month (situation in 2001). ${ }^{28}$

Kitchen smoke disposal was not significantly associated with URI ( $p$ value $=0.310$ ). This means that any comparison with the kitchen ventilation and kitchen floor area had the same effect on the incidence of URI among toddlers. It was influenced by the amount of air pollution generated from biomass burning while cooking in the kitchen. Frequency of presence of children in the kitchen while her mother was cooking was also be one of the factors that must be considered in relation to URI. Another stuff that must be added was measurement of pollutants in the kitchen. Variable the importance of kitchen smoke disposal facilities was actually related to air pollution generated from biomass burning in the kitchen. This result was different from cross-sectional study at the primary health care in North Bangli in 100 houses. Most of the kitchen disposal in the house was unqualified according to health standards. Statistical test using the chi-square showed that the area of house ventilation related to URI with the relation strength was middle scale. ${ }^{29}$

Density was associated with URI on bivariable analysis $(\mathrm{p}$ value $=0.030 ; \mathrm{OR}=2.518(95 \% \mathrm{CI}=1.073-$ $5.911))$ and the binary regression analysis $(\mathrm{p}=0.021$; $\mathrm{OR}=2.843(95 \% \mathrm{CI}=1.168-6.920)$. This means that children living in the dense house had 2.843 times higher risk exposed to URI compared with children living in less dense house. This study is the same as case-control study on children aged of $0-5$ years old who suffered from URI and looked for treatment at Karangnongko Primary Health Care on March - April 2009 in Klaten. Chi-square test results obtained $\mathrm{p}$ value $=0.000(\mathrm{p}<$ 0.05 ) which means that there was a significant relation between residential density with the incidence of respiratory disease among children. In other words, density proven to be a risk factor for respiratory disease with OR $=4.235$ showed that children living in dense house had risk 4.235 times higher than with children living in not dense houses. ${ }^{25}$ The transmission of URI spread quickly in the dense house because of contact with the sufferers carrying the agent of the diseases. ${ }^{30}$

None of the maternal behavior factors was related to URI. Hand-washing was not significantly associated with the incidence of URI ( $\mathrm{p}$ value $=0.820 ;$ OR $=1.07(0.55$ to 2.08)). This study did not observe in hand-washing because of the time limit, also this study only used likert scale questionnaire to measure hand-washing. It was different from study on the relation between hand-washing and the risk of respiratory infections in the systematic review by searching various articles conducted prior to June 2004 as it was found that hand-washing could lower the risk of respiratory disease by $16 \%$ (95\% CI $11-$ $21 \%$ ). However, the implications of this discovery for developing countries is not significant because the geographical limitations. ${ }^{15}$

The use of mask was not significantly associated with URI $(\mathrm{p}$ value $=0.91 ; \mathrm{OR}=0.96(95 \% \mathrm{CI}=0.50-1.85)$. There was no standards in measuring the use of mask and no instructions on how to use the mask properly to 
prevent URI. Also, the time required to wear a mask to prevent URI was still difficult because of unknown incubation period. The use of mask sometimes must be done before the onset of disease symptoms. It will need further study to show the association between the use of mask with URI. 31,32

Mothers' smoking behavior was not significantly associated with URI ( $\mathrm{p}$ value $=0.097$; OR $=0.424(95 \%$ $\mathrm{CI}=0.151-1.193)$ ). Measurement of smoking behavior would be better with observations, while in this study did not observe such behavior. Mothers' smoking behavior was not significant because children were far from their mothers when the mothers were smoking. 33

Vitamin A consumption was not significantly associated with URI ( $\mathrm{p}$ value $=0.483 ; \mathrm{OR}=1.647(95 \% \mathrm{CI}=$ $0.424-6.396)$ ) because of the vitamin A coverage of West Java was good as this study suspected. Coverage of infants who received vitamin A was $84.18 \%$ and the coverage of toddlers who received vitamin A was $83.85 \% .13$ This case needs further study regarding how important vitamin A on respiratory tract. Exclusive breastfeeding was not significantly associated with URI ( $\mathrm{p}$ value = 0.425 ; OR $=0.758(95 \% \mathrm{CI}=0.384$ to 1.498$)$ ). Exclusive breastfeeding is one source to enhance the immune system of infants. When viruses and bacteria come, then the immune system will fight it. Other factors should also be considered here for URI. In addition, the amount of milk as well as the length of time given also affected the function of the children's immune system. Even though it was different with the study conducted in Aceh, but they suggested health workers to improve the health promotion programs, especially regarding exclusive breastfeeding and complementary feeding for infants with a focus on mothers and prospective mothers. The mothers are also expected to pay more attention to the age of complementary feeding for infants that are not easily infected. 34,35

\section{Conclusion}

In this study, household environment significantly related to URI were humidity and density. However, humidity seems to be the protective factor against URI. House humidity that does not meet the criteria does not cause URI. This is related to the frequency of childen settled at house. Toddlers often play outside the house, so the URI transmission could have come from childhood friends. Otherwise, toddlers living in houses that do not meet the criteria have 2.8 times risk of suffering from URI compared to the houses that meet the criteria. None of maternal behavior factor is related to URI. These results need further studies to observe the maternal behaviors related to URI with longer period of time. Finally, the most influential factor significantly related to URI is density. Reducing density is important and challenging issue in slum area. Consequently, increasing health promotion, healthy hygienic behavior and prevention from URI is essential to reduce the risk of this disease among toddlers in urban slum area.

\section{Acknowledgement}

The author greatly thanks to Prof. Cissy Rachiana S.P., $\operatorname{SpA}(\mathrm{K})$., $\mathrm{PhD}$ for the advice related to respiratory infection, Dr.Tb. Benito Achmad K. Ir., Dipl. EST for the advice related to household environment, and Irvan Afriandi, dr., Grad. Dipl. OEH., MPH., Dr.PH., as the Head of Master of Public Health, Faculty of Medicine, Padjadjaran University, Bandung, West Java, Indonesia.

\section{References}

1. Schluger NW. The acute respiratory world atlas. 1st ed. Atlanta: Book House Group Inc.; 2010

2. Jones L. Upper respiratory infection. Proquest. 2006: 24-6.

3. Unuvar E, Yildiz I, Kilic A, Aslan SS, Cakal B, Toprak S, et al. Viral etiology and symptoms of acute upper respiratory tract infections in children. Turkish Medical Journal Sciences. 2009; 39 (1): 29-35.

4. Ahmadiafshar A. Upper respiratory tract infection in preschool children. Indian Journal of Maternal and Child Health. 2010; 12(3): 1-7.

5. Hay AD, Wilson A, Fahey T, Peters TJ. The duration of cough in preschool children presenting to primary care: a prospective cohort study. Family Practice. 2003; 20 (6): 696-705.

6. Kasnodiharjo, Elsi E. Deskripsi sanitasi lingkungan, perilaku ibu, dan kesehatan anak. Kesmas: Jurnal Kesehatan Masyarakat Nasional. 2012; 7 (9): 415-20.

7. Pore PD, Gatthargi CH, Rayate MV. Study of risk factor of acute respiratory infection in undefives in Solapur. National Journal of Community Medicine. 2010; 1 (2): 64-7.

8. Williams BG, Gouws E, Boschi-Pinto C, Bryce J, Dye C. Estimates of worldwide distribution of child deaths from acute respiratory infections. Lancet Infectious Diseases. 2002; 2: 25-37.

9. Galih B, Ngazis AN. Akibat perubahan iklim, ISPA mengancam hingga 30 tahun. Jakarta: Viva Media Baru; 2012 [cited 2015 Jun 6]. Available from: http://teknologi.news.viva.co.id/news/read/353278-akibat-perubahan-iklim-ispa-mengancam-hingga-30-tahun.

10. Badan Penelitian dan Pengembangan Kesehatan Kementrian Kesehatan Republik Indonesia. Riset kesehatan dasar (Riskesdas) tahun 2013. Jakarta: Kementrian Kesehatan RI; 2013.

11. Badan Pengelola Lingkungan Hidup Jawa Barat. Sekilas dan kondisi umum daerah Jawa Barat. Jawa Barat: BPLHD Jawa Barat; 2013.

12. Dinas Kesehatan Kota Bandung. Rekapitulasi laporan ISPA per puskesmas. Bandung: Dinas Kesehatan Kota Bandung; 2013.

13. Dinas Kesehatan Provinsi Jawa Barat. Profil kesehatan Jawa Barat tahun 2012. Bandung: Dinas Kesehatan Provinsi Jawa Barat; 2012.

14. Koch A, Molbak K, Homoe P, Sorensen P, Hjuler T, Ehmer M, et al. Risk factors for acute respiratory tract infections in young Greenlandic children. American Journal Epidemiology. 2003;158: 374-84.

15. Rabie T, Curtis V. Handwashing and risk of respiratory infection: a systematic review. Tropical Medicine and International Health. 2006; 11 (3): 258-67. 
16. Mishra V, Smith KR, Retherford RD. Effects of cooking smoke and environmental tobacco smoke on acute respiratory infections in young Indian children. Population and Environmental. 2005; 26 (5): 375-96.

17. Luby SP, Agboatwalla M, Feikin DR, Painter J, Altaf A, et al. Effect of handwashing on child health: a randomised controlled trial. Lancet Infectious Diseases. 2005; 366: 225-33.

18. Dugdale DC. Upper respiratory tract. Bethesda: A.D.A.M., Inc.; 2014 [diunduh 29 Oktober 2014]. Available from: http://www.nlm.nih.gov/medlineplus/ency/imagepages/19378.htm.

19. Behrman RE, Kliegman RM, Jenson HB. Nelson textbook of pediatrics. $17^{\text {th }}$ ed. United States of America: Saunders; 2003.

20. Van Deer Gag EJ, Van Droffelaar N. Upper respiratory tract infections in children: A normal stage or high parental concern? Journal of Pediatrics. 2012; 2: 244-9.

21. Departemen Kesehatan Republik Indonesia. Pedoman tekhnis penilaian rumah sehat. Jakarta: Departemen Kesehatan Republik Indonesia; 2002.

22. Kementerian Kesehatan Republik Indonesia. Pedoman penyehatan udara dalam ruang rumah nomor 1077/Menkes/Per/V/2011. Jakarta: Departemen Kesehatan Republik Indonesia; 2011.

23. RTI International. Health literacy skills instrument user guide. New York: RTI International; 2010.

24. Bann CM, Mccormack LA, Berkman ND, Squiers LB. The health literacy skills instrument : a 10-items short form. Journal of Health Communication. 2012;17 (Suppl 3): 191-202.

25. Nurhiadayati I, Fitriah N. Lingkungan fisik rumah dengan kejadian penyakit ISPA pada balita di wilayah kerja Puskesmas Karangnongko Kabupaten Klaten tahun 2009. Motorik Jurnal Ilmu Kesehatan (Journal Of Health Science). 2010; 5 (9).

26. Yusup NA, Sulistyorini L. Hubungan sanitasi rumah secara fisik dengan kejadian ISPA pada balita. Jurnal kesehatan lingkungan. 2005; 1 (2):
110-9.

27. Makinen TM, Juvonen R, Jokelainen J, Harju TH, Peitso A, Bloigu A, et al. Cold temperature and low humidity are associated with increased occurrence of respiratory tract infections. Respiratory Medicine. 2009; 103: 456-62.

28. Kementerian Pekerjaan Umum dan Perumahan Rakyat. Tentang rumah sehat 2010 [cited 201518 September]: Available from: http://www.pnpmperkotaan.org/wartaarsipdetil.asp?mid=3049\&catid= $2 \&$.

29. Juniartha SK, Hadi HMC, Notes N. Hubungan antara luas dan posisi ventilasi rumah dengan kejadian ISPA penghuni rumah di wilayah Puskesmas Bangli Utara tahun 2012. Jurnal Kesehatan Lingkungan. 2014; 4 (2):169-74.

30. Asriati, Zamrud M, Kalenggo DF. Analisis faktor risiko kejadian infeksi saluran pernapasan akut pada anak balita [manuscript on internet]. Kendari: Universitas Haluoleo; 2012.

31. Tracht SM, Valle SYD, Hyman JM. Mathematical modeling of the effectiveness of facemasks in reducing the spread of novel influenza a (H1N1). Plos One. 2010; 5 (2): 1-12.

32. Daniels TL, Talbot TR. Unmasking the confusion of respiratory protection to prevent influenza-like illness in crowded community settings. Journal Infectious Diseases. 2010; 201: 483-5.

33. Trisnawati Y, Juwarni. Hubungan perilaku merokok orang tua dengan kejadian ISPA pada balita di wilayah kerja Puskesmas Rembang Kabupaten Purbalingga 2012 2012:1-8.

34. Nur A, Marisa N. Riwayat pemberian Air Susu Ibu dengan penyakit infeksi pada balita. Kesmas: Jurnal Kesehatan Masyarakat Nasional. 2014; 9 (2): 144-9.

35. Widarini, Sumasari. Hubungan pemberian ASI Eksklusif dengan kejadian ISPA bayi. Jurnal Ilmu Gizi. 2010; 1 (1): 28-41. 